\title{
AS POLÍTICAS PÚBLICAS URBANAS BRASILEIRAS E A GESTÃO DEMOCRÁTICA: O CONTROLE SOCIAL NA EFETIVAÇÃO DO DIREITO À CIDADE
}

\section{BRAZILIAN PUBLIC URBAN POLICIES AND DEMOCRATIC MANAGEMENT: SOCIAL CONTROL ON EFFECTIVENESS OF THE RIGHT TO THE CITY}

\author{
Emerson Affonso da Costa Moura ${ }^{1}$
}

\section{Resumo}

O papel exercido pelo controle social na garantia da efetividade das políticas públicas urbanas é o tema posto em debate. Analisa-se em que medida os instrumentos de gestão democrática são capazes de garantir no âmbito dos planos de ação urbanística a efetividade do direito à cidade e do cumprimento de suas funções sociais. Para tanto, de início investiga-se as políticas públicas enquanto planos de ação que garantem as prestações necessárias à concretização dos direitos fundamentais. Após, verificam-se os programas de ação urbanísticas desenvolvidos e o controle exercido pela sociedade. Por fim, o papel que o controle social tem através da gestão democrática na correição das políticas urbanas para realização do direito à Cidade.

Palavras-chave: Políticas Públicas; Políticas Urbanas; Gestão Democrática; Controle Social; Direito à Cidade.

\section{Abstract}

The role played by social control in ensuring the effectiveness of urban public policy is the theme put into discussion. It is analyzed to what extent the democratic management tools are able to secure within the urban action plans the effectiveness of the right to the city and the fulfillment of its social functions. To do so, initially we investigate public policy as action plans that guarantee benefits for the achievement of fundamental rights. After, are verified the developed urban action programs and the control exercised by society. Finally, the role that social control is through democratic management in the eyre of urban policies for realization of the right to the city.

Keywords: Public Policy; Urban Policies; Democratic management; Social control; Right to the City.

\footnotetext{
1 Professor Assistente da Universidade Federal de Juiz de Fora (UFRJ). Doutorando em Direito pela Universidade do Estado do Rio de Janeiro (UERJ). Mestre em Direito Constitucional e Pesquisador Certificado pelo CNPQ na Universidade Federal Fluminense (UFF). E-mail: emersonacmoura@yahoo.com.br
} 


\section{INTRODUÇÃO}

Para a realização dos objetivos sociais e econômicos almejados e o oferecimento das prestações e utilidades necessárias a concretização dos direitos fundamentais, o Estado planeja e executa um conjunto articulado de programas e ações que é usualmente designado como políticas públicas.

No âmbito urbanístico tem capital importância por buscar a realização das funções sociais da Cidade permitindo através de ações governamentais planejadas e coordenadas o oferecimento de bens, equipamentos e serviços públicos capazes de garantir aos proprietários, moradores e usuários a realização de moradia, trabalho, lazer, mobilidade dentre outros.

Todavia, as políticas públicas urbanas embora iniciadas ainda na Colônia não foram capazes de garantir a infraestrutura e os serviços necessários para atender as demandas sendo agravado no Império onde ampliou a segregação espacial das ações, que na República com a ampla migração e crescimento da pobreza maximizam os problemas da Cidade.

Embora tais programas e ações urbanísticas se ligam a concretização do direito à Cidade foram veiculados às políticas e ciclos econômicos, bem como, as demandas do mercado imobiliário, ao revés der ser orientado pelas eleições realizadas pela sociedade nas leis fundamentais ou através das demandas realizadas dentro de um efetivo processo democrático.

Neste contexto, o controle exercido diretamente pela sociedade sob as políticas públicas urbanas pode se tornar um instrumento capaz de conformar o planejamento e execução aos fins socialmente almejados garantindo, portanto, que os recursos financeiros e administrativos investidos, bem como, os planos e ações realizadas sejam capazes de atingir aqueles fins.

Busca o presente trabalho, portanto, analisar em que medida a gestão democrática da Cidade é capaz enquanto instrumento de controle social do planejamento e implementação das políticas públicas permitir que sejam direcionadas as ações governamentais as funções sociais e ao direito à Cidade.

Para tanto, de início investiga-se as políticas públicas em seus elementos gerais, de forma a extraí-la não como decisões políticas livres, mas planos de ação que devem garantir as prestações, bens, utilidade e serviços necessários à concretização dos direitos fundamentais, dentre os quais, o direito à Cidade.

Após, verifica-se os planos e programas de ação urbanísticos realizados desde a Colonização até a última quadra histórica, de maneira a determinar através de sua vinculação aos 
interesses econômicos do mercado a sua ineficiência no desenvolvimento das Cidade, o que denota a importância do controle social como forma de reconduzí-lo aos interesses sociais.

Por fim, estuda-se o controle social em suas modalidades e importâncias extraindo os mecanismos trazidos pelo Estatuto da Cidade que ao trazer como princípio a gestão democrática da cidade e prever instrumentos de controle do planejamento e execução da ação governamental pode contribuir com maior eficácia nas políticas públicas urbanas.

\section{POLÍTICAS PÚBLICAS E OS DIREITOS FUNDAMENTAIS}

Políticas públicas são os programas, planos e diretrizes de ação governamental que coordenam a alocação da estrutura, bens e agentes disponíveis, harmonizando as atividades estatais e privadas, os variados atores e múltiplos interesses envolvidos na realização destes objetivos socialmente relevantes e politicamente determinados².

As políticas públicas, portanto, compreende além da colocação a disposição dos recursos de forma a garantir a prestação imediata de serviços públicos pelo Estado, a atuação normativa, reguladora e de fomento que combinadas de forma eficiente conduzem os esforços da esfera pública e privada, na consecução dos fins almejados pela Constituição e a sociedade 3 .

De certo modo, há uma complexidade na apreensão do tema, pois a exteriorização dos programas governamentais não se apresenta com um padrão uniforme facilmente apreensível pelo sistema jurídico. Se por um lado, há uma visível proximidade com os planos ou processo, as políticas públicas antes englobam do que resumem os atos que as conformam ${ }^{4}$.

Aprioristicamente restringem-se a função política do Governo como atos decisórios que implicam na fixação de metas, diretrizes ou planos governamentais ${ }^{5}$. Todavia, conforme insertas no

\footnotetext{
2 Sob este foco, correspondem a instrumentos de ação de governo utilizados para alcançar as metas e objetivos coletivos, que redireciona o eixo da atuação estatal e da organização do governo das leis government by law para as políticas government by polices. BUCCI, Maria Paula Dallari. Direito Administrativo e Políticas Públicas. São Paulo: Saraiva, 2002. p 241-244 e 252-253.

3 Predomina em sua natureza, a intervenção cogente do Estado na realização dos bens e valores sociais, razão pelo qual, não englobam os programas realizados em associação com a sociedade civil, através de mecanismos e instrumentos institucionais ou não. BARCELLOS, Ana Paula de. Constitucionalização das Políticas Públicas em Matéria de Direitos Fundamentais: O Controle Político-Social e o Controle Jurídico no Espaço Democrático in Revista de Direito do Estado. Ano 1. n. 3. 2006. p. 18 e 22.

4 As políticas públicas, portanto, distinguem-se das categorias das normas e atos jurídicos, embora compreenda esses elementos. Sob este foco, aproxima-se do conceito de atividade, enquanto conjunto organizado dessas normas e atos tendentes à realização de um objetivo determinado. BUCCI, Maria Paula Dallari. Ob. cit. 251-257.

5 Trata-se de função política do Estado uma vez que corresponde à atividade dos órgãos estatais com a finalidade de conservação da sociedade política e da definição e prossecução do interesse geral mediante a
} 
quadro dinâmico de ação estatal, informadas por elementos de expertise e dependentes da estrutura burocrática, também alçam a esfera da função administrativa ${ }^{6}$.

Não obstante, a dificuldade na definição de sua natureza, as políticas públicas podem ser exteriorizadas em um ciclo que compreende a delimitação das metas e prioridades com o planejamento dos programas de atuação estatal, a alocação dos recursos públicos na execução destes planos e a avaliação dos impactos da ação governamental no oferecimento dos bens e serviços sociais ${ }^{7}$.

De início, o planejamento compreende o processo dialético construído a partir das demandas sociais inputs e apoios políticos e burocráticos withimputs, que resulta na escolha racional e coletiva das metas e prioridades públicas, imprimindo na gestão estatal a direção geral da política adotada pelo governo e a satisfação das necessidades sociais ${ }^{8}$.

Neste tocante, envolve a prévia identificação dos interesses em conflito oriundo dos distintos segmentos sociais, a avaliação dos fatores subjacentes - econômicos, técnicos, políticos e afins - pelo seu gabinete e a formulação das possíveis soluções que permitam a tomada de decisão pelo agente eleito das ações necessárias para o atendimento das demandas.

Consolida-se no campo político-administrativo através dos planos e programas de caráter geral ou setorial criados pelo governo, com a definição das diretrizes, metas e objetivos almejados e delineamento dos projetos, ações e atividades a ser implementados a médio ou curto prazo para alcançá-los mediante o oferecimento dos bens e serviços públicos.

No âmbito financeiro-orçamentário importa na orientação da alocação prévia e abstrata dos recursos estatais destinados aos planos e programas de governo no orçamento público através

escolha dentre as soluções possíveis exteriorizada em planos ou programas. CAETANO, Marcello. Manual de Ciência Política e de Direito Constitucional. Coimbra: Almedina, 2003. p. 172.

${ }^{6}$ A Administração Pública exerce um papel relevante não apenas na execução das políticas públicas, mas influencia a ação governamental auxiliando no desenho institucional do programa governamental ou subsidiando as complexas questões envolvidas na sua formulação, mediante o conhecimento e a expertise de seus agentes. Sobre o tema: MOURA, Emerson Affonso da Costa. Agências, Expertise e Profissionalismo: 0 Paradigma da Técnica na Administração Pública. Revista de Direito Administrativo, FGV, Rio de Janeiro, v. 254, p. 79, 2011.

${ }^{7}$ As políticas públicas possuem uma configuração cíclica e não de um processo linear, uma vez que suas fases não atuam de formas isoladas e ordenadas, porém, conexas, sobrepostas e abertas a elementos externos, que torna possível surgir na avaliação a verificação de novas demandas ou na execução a necessidade simultânea de reformulação dos planos. MENY, Ives e Thoenig, Jean Claude. Lãs políticas públicas. Barcelona: Ariel, 1992. p. 16.

8 Sobre a experiência brasileira de planejamento e as estratégias definidas para equacionar as dificuldades surgidas, vide: COELHO NETO, Milton. A Transparência e o Controle Social como Paradigmas para a Gestão Pública no Estado Moderno in: FIGUEIREDO, Carlos Maurício e NÓBREGA, Marcos. Administração Pública: Direito Administrativo, Financeiro e Gestão Pública: Prática, Inovações e Polêmicas. São Paulo: Revista dos Tribunais, 2002. 
das leis orçamentárias, com a delimitação das unidades orçamentárias responsáveis e a sua compatibilização com as metas fiscais e as receitas públicas disponíveis ${ }^{9}$.

Embora o espaço decisório na formulação das ações governamentais, esteja precipuamente circunscrito a seara do jogo político - em razão do princípio democrático e da especialização funcional explicitadas na reserva de administração veiculada pela Constituição - isto não significa que a sua materialização nos instrumentos orçamentários ocorra de forma livre.

Isto porque, existem fins esperados e exigíveis das políticas públicas, exteriorizado nos bens e interesses tutelados pela Constituição, inclusive, com o estabelecimento de prioridades e a definição de matérias e dispêndio de recursos públicos, que vinculam os poderes públicos no planejamento construindo no espaço da decisão política limites objetivos invioláveis ${ }^{10}$.

Ademais, sua legitimidade decorre da observância do consenso obtido na deliberação pública acerca da diretiva político-administrativa almejada pela sociedade para a gestão pública, de forma que os programas governamentais propostos pelo agente político durante a plataforma eleitoral e ratificados pelos cidadãos no processo eletivo não podem ser ignorados no exercício do poder $^{11}$.

Por efeito, é possível identificar na formulação das políticas públicas um núcleo intangível para deliberação política, que corresponde aos objetivos e fins coincidentes com a diretiva política traçada pela Constituição e escolhida pelo processo majoritário e um campo adstrito a atividade política, que abrange como serão alcançadas essas diretrizes na tomada de decisão pelo governo ${ }^{12}$.

\footnotetext{
${ }^{9}$ Compreende o planejamento, portanto, em um primeiro estágio, a criação do plano geral de governo (artigo 84 inciso XI) e dos planos nacionais, regionais ou setoriais de ordenação do território e de desenvolvimento econômico e social (artigo 21 inciso IX, 174 §1ㅇ, 214, 180, 225 e outros). Em um segundo momento, abrange a expressão orçamentária das políticas públicas no plano plurianual (artigo 165 inciso I) e nas leis de diretrizes orçamentárias (artigo 165 inciso II) e orçamentos anuais (artigo 165 inciso III todos da Constituição da República).

${ }^{10}$ Há casos em que a Constituição consagra de forma explícita os fins esperados das políticas públicas, como ocorre com o oferecimento obrigatório de educação fundamental gratuita (artigo 208) ou determina o dispêndio mínimo dos recursos para estes, inclusive, com a vinculação das receitas oriundas do imposto, como acontece com a saúde (artigo 167 inciso IV e 198 §2º), produzindo resultados esperados e exigíveis das políticas públicas. Também neste sentido: BARCELLOS, Ana Paula de. Ob. cit. p. 37.

$11 \mathrm{O}$ crescente distanciamento entre as propostas veiculadas no âmbito da propaganda eleitoral e a condução da gestão pública, que não raro elegem políticas públicas incompatíveis com as reais expectativas da sociedade - como custeio de obras faraônicas ou propagandas dispendiosas apesar da deficiência na prestação de serviços públicos, contribui para ampliação do déficit de legitimidade das instituições representativas e a crise de governança das instituições políticas, erigindo a necessidade de instrumentos para controle dos programas governamentais pela sociedade. DAL BOSCO, Maria Goretti. Discricionariedade em políticas públicas. Curitiba: Juruá, 2007. p. 251.

12 Nos instrumentos financeiros, corresponde à vinculação da elaboração do orçamento público em consonância com as prioridades constitucionais e os planos governamentais, de forma a permitir a realização
} 
A execução das políticas públicas compreende o conjunto de ações que permitam a concretização dos bens e interesses socialmente almejados, através da alocação de estrutura, recursos e agentes de acordo com as metas e prioridades previamente estabelecidas nos planos e programas de direção da ação governamental visando à realização dos preceitos constitucionais.

Realiza-se, portanto, notadamente no campo administrativo através da programação executiva dos planos de governo aprovados, em um conjunto de processos que importam no emprego dos recursos administrativos, materiais e humanos pelos sujeitos estatais e não-estatais resultando no oferecimento dos bens e serviços a sociedade output.

$\mathrm{Na}$ esfera financeira, abrange a execução orçamentária com a utilização dos créditos ordinários e adicionais consignados no orçamento que definem a quantidade de dispêndio dos recursos financeiros para o atendimento das despesas públicas e financeira com o efetivo emprego destes pelas unidades orçamentárias no atendimento das políticas públicas.

Trata-se de processo dinâmico que demanda constante adaptação no desenho institucional das políticas públicas, inovação na implementação das respectivas ações estatais e monitoramento das estratégias empregadas, de forma a garantir a superação das questões complexas surgidas e a obtenção de resultados dotados de celeridade e eficiência. ${ }^{13}$

Sobressai a atuação da Administração Pública no complexo de operações realizadas que coordenam os diversos vetores aos resultados esperados, reservando-se aos centros de comando estatais a função de monitoramento do processo, dimensionando a execução às dificuldades operacionais e políticas surgidas da realidade subjacente.

Del tal sorte, observa-se que o espaço decisório dos poderes públicos na execução dos programas governamentais também não é limitado, em decorrência da inexistência de liberdade absoluta no domínio da discricionariedade administrativa, enquanto faculdade de escolha dentre os indiferentes jurídicos na esfera de atribuição concedida pela norma jurídica.

dos direitos fundamentais e garantir a segurança jurídico-orçamentária aos cidadãos, impedindo gastos irrazoáveis com propagandas, festas e obras faraônicas. Neste sentido: LEITE, Fereira Harrison. Segurança Jurídica e Elaboração do Orçamento Público. Revista Tributária e de Finanças Públicas. n 86 mai/jul 2009. p. 113 e 147-148.

${ }^{13}$ Em grande medida, a implementação das políticas públicas correspondem a uma formulação em processo, uma vez que não se encontra inserida em um ambiente onde há informação perfeita sobre o conteúdo dos programas de ação governamental ou problemas previamente conhecidos, mas sujeitas a superação de dificuldades como por e.g. a falta de acesso a informações, inviabilidade dos programas, limitações de tempo e de recursos, linhas múltiplas de comando, as contingências da sociedade e influências políticas no processo dentre outras. SILVA, Pedro Luiz Barros e MELO, Marcus André Barreto de.O Processo de Implementação de Políticas Públicas no Brasil: Características e Determinantes da Avaliação de Programas e Projetos. Caderno do Núcleo de Estudos de Políticas Públicas da Unicamp n. 48. p. 8. 
A implementação das políticas públicas deve ocorrer mediante ações, programas e projetos adequados ao atendimento das prioridades - expressa nos objetivos e fins socialmente almejados - e às vinculações - estatuída na alocação e execução dos recursos públicos - traçados pela Constituição e pelos planos políticos nas respectivas leis materiais e formais.

Sob esta égide, o campo de decisão política ou administrativa na execução dos programas governamentais compreende uma livre eleição, todavia, dentre os meios e atividades que sejam capazes de atender com eficiência as metas, objetivos e diretrizes que ordenam a ação estatal, garantindo sejam alcançados os resultados esperados das políticas públicas ${ }^{14}$.

No emprego dos recursos financeiros a discricionariedade administrativa, permite contingências nas dotações buscando promover o equilíbrio da gestão orçamentária e atender o interesse público superveniente, porém, adstrito a observância da eficiência na sua alocação e dispêndio, capaz de garantir uma persecução dos fins e interesses socialmente almejados ${ }^{15}$.

Por fim, a avaliação das políticas públicas envolve a correlação causal entre o programa promovido e o resultado alcançado, de forma a extrair os efeitos e impactos na promoção dos direitos sociais, identificando as ações eficientes ou promovendo o desenho de alternativas que permitam alcançar os fins socialmente desejados.

Compreende a avaliação concomitante dos processos de execução das políticas públicas ou posterior dos resultados da ação governamental, mediante o controle da efetividade dos programas propostos, da validade das estratégias utilizadas na sua implementação e o monitoramento da eficiência gerencial e operacional obtida pela ação estatal.

Baseia-se nos dados objetivos alcançados mediante a enunciação dos elementos determinantes e indicadores das ações utilizadas no planejamento e execução das políticas públicas, que permitem a criação de estudos avaliativos capazes de diagnosticar a eficiência dos processos e resultados no oferecimento dos bens e interesses socialmente almejados.

\footnotetext{
${ }^{14}$ Corresponde, portanto, a sujeição a limites que garantam a eleição de meios capazes de alcançar os fins esperados dos programas governamentais. Isto porque, de nada adiantaria, por e.g. a Constituição ordenar a promoção de políticas públicas que garantam acesso universal e igualitário à medicina preventiva, curativa e de urgência (art.196), se houver na execução escolha de ações de eficácia limitada ou nula, como por exemplo, utilização de terapias alternativas sem comprovação científica no tratamento médico de urgência ou se na execução orçamentária for utilizado constantemente as transferência entre rubricas e contingenciamento dos recursos públicos.

${ }^{15}$ Esta discricionariedade administrativa tem sido mitigada pelo ingresso de novos atores e procedimentos na prática orçamentária, e.g, em razão das titulações ou criações de direitos subjetivos fixados pela legislação e o Poder Judiciário, os tributos finalísticos e outros. Sobre o tema, consulte: TORRES, Ricardo Lobo. Tratado de Direito Constitucional, Financeiro e Tributário: O Orçamento na Constituição. 3. ed. Rio de Janeiro: Renovar, 2008 p. 457-458.
} 
Esta verificação e análise dos resultados competem precipuamente aos órgãos políticos, como forma de garantir maior transparência e eficiência na gestão pública, qualificando a intervenção dos atores envolvidos e viabilizando com o acesso às informações e os dados obtidos, os mecanismos de controle social e de responsabilização política ${ }^{16}$.

Da mesma forma como o planejamento e a execução sujeitam-se a limites que visam a preservar a legitimidade da ação estatal - aferidas na identidade dos fins e na adequação dos meios escolhidos com os objetivos traçados na Constituição e no processo eleitoral - inexiste na avaliação das políticas públicas um espaço decisório amplo para os poderes públicos ${ }^{17}$.

Orienta-se a avaliação pela dialética formada entre os resultados obtidos mediante os projetos e ações implementadas e aqueles que eram legitimamente esperados das políticas públicas, alcançados mediante a promoção dos bens e serviços públicos, dentro das razoáveis expectativas da sociedade que concorreu com os recursos estatais e a eleição dos agentes ${ }^{18}$.

Por esta razão, o processo de avaliação das políticas públicas, que resulta na decisão pelos poderes públicos sobre a manutenção, correção ou exclusão dos planos governamentais propostos e das ações estratégicas implementadas é condicionado ao grau de eficiência obtida na concretização dos fins e interesses socialmente almejados ${ }^{19}$.

\footnotetext{
${ }^{16}$ Ademais, com a análise e avaliação das políticas públicas, completa-se o círculo legitimador, uma vez que os resultados alcançados justificam a preservação dos meios utilizados ou a sua reconfiguração de forma a garantir os fins desejados, prevenindo a consolidação de uma atuação ineficaz ou a falta de continuidade na prestação dos bens ou serviços públicos. VALLE, Vanice Lirio do. Direito fundamental a boa administração, Políticas Públicas Eficientes e a Prevenção do Desgoverno. Revista Interesse Público, n. 48 mar/abr de 2007.

17 Inexistindo liberdade plena dos agentes políticos na definição dos programas de ação governamentais diante dos fins esperados e dotações determinadas pela Constituição - e de sua execução - em razão da necessária relação de adequação dos meios empregados aos objetivos necessários - resulta que tão pouco na avaliação - com a definição dos resultados alcançados e da análise da eficácia dos projetos propostos e das medidas utilizadas - haja um espaço decisório que permitam sejam traçadas ou mantidos ações que não permitam a realização eficiente daqueles fins.

${ }^{18}$ Disto decorre que não basta serem garantido processos legítimos e eficientes no planejamento e execução das políticas públicas, mas resultados concretos e materializados em uma boa e justa atribuição de bens e serviços aos cidadãos que permitam sua utilização eficiente. MOREIRA NETO, Diogo de Figueiredo. Quatro Paradigmas do Direito Administrativo Pós-Moderno. Belo Horizonte: Fórum, 2008. p. 135-136.

${ }^{19} \mathrm{Em}$ razão disto, não é possível a manutenção de uma política pública ineficiente ou a exclusão de ações governamentais que possuem eficácia comprovada, ao menos sem a sua substituição por outra hábil a alcançar resultados idênticos ou superiores. Neste ponto, entra em contato com o princípio da proibição de vedação do retrocesso social, que veda supressão da norma jurídica definidora de direitos sociais ou de sua conseqüente concretização por meio de atos normativos ou executivos que impeçam a fruição dos bens e interesses sociais sem que sejam criados mecanismos equivalentes ou compensatórios.DERBLI, Felipe. Proibição de Retrocesso Social: Uma Proposta de Sistematização à Luz da Constituição de 1988 in: BARROSO, Luís Roberto (Org). A Reconstrução Democrática do Direito Público no Brasil. Renovar: Rio de Janeiro, 2007. p. 494-495.
} 
De modo que, erige-se como parâmetro de avaliação dos planos, programas e diretrizes governamentais, determinante de sua continuidade, redimensionamento ou substituição, o resultado qualificado pela eficiência ou ineficiência obtido pela ação estatal na realização dos objetivos traçados pela Constituição e escolhidos pelo processo majoritário.

De todo exposto, observa-se que as políticas públicas correspondem a instrumentos de efetivação dos direitos fundamentais, que permitem através de um complexo de ações políticoadministrativas coordenadas, quando observado os eventuais limites nos espaços decisórios, uma prestação dos bens e serviços públicos dotada de eficiência e legitimidade.

Isto porque com o reconhecimento da força normativa da Constituição ${ }^{20}$ substitui-se a concepção da lei fundamental como carta política com a atribuição do status de norma jurídica, que dotada de observação obrigatória, impõe no exercício do poder pelo Estado, limites e deveres de atuação, em especial, na tutela dos direitos fundamentais. ${ }^{21}$

Por efeito, a concretização dos direitos fundamentais reclama em um maior grau a realização de sua dimensão positiva, mediante adjudicações de prestações pelo Estado de natureza participativa, normativa e material, com a criação e colocação à disposição de seus titulares os bens materiais e imateriais necessários a fruição dos bens e interesses tutelados ${ }^{22}$.

Todavia, não se podem ignorar os dados trazidos pela realidade. A gestão pública é marcada por uma estrutura deficitária, desperdício de recursos, desvios de verbas e ineficiência dos agentes estatais, que resultam na precariedade dos serviços prestados na promoção dos direitos sociais e tornam necessária a definição de controle de políticas públicas ${ }^{23}$.

\footnotetext{
20 Uma das obras percussoras sobre o tema é A força normativa da Constituição de Konrad Hesse extraída a partir de sua aula inaugural na cátedra da Universidade de Freiburg. Segundo o autor, a norma constitucional não tem existência autônoma em face da realidade, mas tão pouco se limita ao reflexo das condições fáticas. Sua essência reside na pretensão de eficácia, ou seja, de sua concretização na realidade imprimindo-lhe ordem e conformação. HESSE, Konrad. A força normativa da Constituição. Porto Alegre: Sergio Antonio Fabris Ed., 1991. p. 14-15.

${ }^{21}$ Sobre as transformações do direito constitucional contemporâneo, consulte-se por todos: BARROSO, Luís Roberto. Neoconstitucionalismo e constitucionalização do direito: O triunfo tardio do direito constitucional no Brasil. In: SOUZA NETO, Cláudio Pereira de; SARMENTO, Daniel (orgs.). A constitucionalização do direito: fundamentos teóricos e aplicações específicas. Rio de Janeiro: Lumen Juris, 2007. p. 203-250. Para uma análise crítica vide: SARMENTO, Daniel. O neoconstitucionalismo no Brasil: Riscos e possibilidades. In: (org.). Filosofia e teoria constitucional contemporânea. Rio de Janeiro: Lumen Juris, 2009. p. 113-146.

${ }^{22}$ Isto não importa desconhecer que a concretização dos direitos sociais também depende da sua realização na dimensão negativa ou que possuem uma eficácia em relação aos particulares, impondo restrições aos direitos e liberdades ou determinando o cumprimento de dadas prestações como ocorre com as contribuições sociais. MIRANDA, Jorge. Manual de Direito Constitucional. Tomo 4. Coimbra: Coimbra Editores, 2002.p. 341-342.

${ }^{23}$ Isto resta exemplificado na pesquisa que aponta que os recursos destinados à área social dos três níveis federativos em todas as regiões do país em 1995 eram três vezes maiores que o volume de recursos
} 
O controle político dos programas de ação governamental realizado pelo Poder Legislativo, embora dotado de instrumentos jurídicos eficientes para fiscalização ${ }^{24}$ têm se demonstrado incapaz de atribuir responsabilidade aos agentes públicos e garantir a correção na persecução dos interesses sociais ${ }^{25}$.

Em um contexto, de redução do processo democrático às deliberações majoritárias, a gestão e controle das políticas públicas no âmbito da esfera política são marcadas por corrupção, ineficiência e clientelismo, que geram o atendimento precário dos interesses públicos e o deslocamento da responsabilização aos agentes para o controle judicial ${ }^{26}$.

No âmbito das políticas públicas urbanas a falta efetiva de controle social tem gerado distorções na efetividade dos planos de ação governamental propostos e implementados, uma vez que há a inexistência de adequamento efetivo às demandas da Cidade e a falta de correição pelos cidadãos.

O tema será tratado a seguir.

\section{AS POLÍTICAS PÚBLICAS URBANAS E O CONTROLE SOCIAL}

No Brasil as políticas públicas urbanas estiveram ligados aos ciclos econômicos brasileiros de forma que ainda quando houve no Império um processo de urbanização não limitado às áreas

necessários para a erradicação da pobreza no Brasil. BARROS, Ricardo Paes, HENRIQUES, Ricardo e MENDONÇA, Rosane. A Estabilidade Inaceitável: desigualdade e pobreza no Brasil. Rio de Janeiro: Ipea, 2001. p. 723.

${ }^{24}$ Compreende dentre outros a sustação de atos e contratos do Executivo (artigo 49 inciso $\vee$ e 71 §1ㅇ) julgamentos de suas contas (artigo 49 inciso IX, artigo 51 inciso II e artigo 57) autorização ou aprovação do Congresso para atos concretos do Executivo (artigo 49 inciso I, XII, XIII, XVI e XVII), instalação de Comissão Parlamentar de Inquérito (artigo $58 \S 3$ ), a suspensão e destituição do Presidente e ministros por crimes de responsabilidade (artigo 85 e 86 todos da Constituição).

${ }^{25}$ Observa-se ainda uma deficiente fiscalização das políticas públicas no controle parlamentar, na atribuição de responsividade aos agentes ou correção de seus atos. Como exemplo, a constante aprovação das contas públicas federais realizadas fora do prazo e desconsideradas as recomendações dos relatórios técnicos ou as manobras políticas que ocorrem nas Comissões Parlamentares de Inquérito que não resultam na atribuição de responsabilidade. OLIVEIRA, Farlei Martins Riccio de. Controle de Legitimidade das Políticas Públicas: Limites e Possibilidades. Revista de Direito Administrativo, 247 jan/abr de 2008 p. 72-73.

${ }^{26}$ Por efeito, há o desperdício no emprego dos recursos públicos nas políticas públicas, sem que se alcance bons resultados na promoção dos direitos sociais e das condições da sociedade participar de forma adequada no processo democrático. Diante da constante troca de favores políticos que não permite uma apuração das responsabilidades, transfere-se para o Poder Judiciário o controle da ação estatal, que representa mais um paliativo do que uma medida capaz de sanar essas dificuldades. BARCELLOS, Ana Paula de. Ob. cit. p. 27. 
litorâneas onde ocorria a exploração de recursos naturais como o pau-brasil, a criação de cidades e vilas foi orientada pela produção de cafée 27 .

Por efeito, gera-se a primeira distorção na formação da cidade brasileira, pois resultarem antes da ação das autoridades estatais do que fruto da própria sociedade ${ }^{28}$, o que aponta junto com os limites do processo democrático, o baixo grau de participação do grupo social na gestão democrática da cidade e do controle nas políticas públicas urbanas.

Inegável que, as cidades sendo responsável pela ligação do campo - local da atividade produtiva - com a metrópole - exímia origem de exportação - e, portanto, papel central na articulação da economia externa gerou por um lado autonomia e centralidade dos núcleos urbanos, porém, também baixa taxa de moradia e desocupação ${ }^{29}$.

Isto porque, as políticas públicas de formação da cidade brasileira no período colonial não seguiram a diretiva da colonização espanhola de tentativa de criação de uma extensão do domínio castelhano, mas de um local pouco povoado, quase não urbanizado e com fins exclusivamente econômicos ${ }^{30}$.

Adota-se, portanto, não os planos urbanísticos de Portugual - com desenhos em xadrez orientados no sentido norte-sul e leste-oeste - pois tinha apenas função econômica - construções temporárias para fins de armazenamento e exportação - e de defesa - em sítio elevados - o que dificultava o arruamento em xadrez e se adequava a concepção ideológica lusitana de não afirmar suas altas qualidades culturais perantes povos submetidos. ${ }^{31}$

De sorte, que enquanto o espaço rural foi marcado pela quase auto-suficiência, os núcleos urbanos já denotavam mazelas sociais - como a miséria e a dificuldade de escoamento de produção - e legados políticos - com a administração urbana sujeita ao poder local e a figura dos "homens bons"32 sendo as cidades dependentes do domínio agrário ${ }^{33}$.

Durante o período de dominação holandesa, as políticas urbanas de Nassau resultou em melhoramento das Cidades, mas gerou efeito pernicioso do amplo processo de migração do campo

\footnotetext{
${ }^{27}$ SILVA, José Afonso da. Direito Urbanístico Brasileiro. 7 ed. São Paulo: Malheiros, 2012. p. 21.

${ }^{28}$ VIANNA, Oliveira. Populações Meridionais do Brasil. Brasília: Senado Federal, 2005. p. 331.

${ }^{29}$ MARICATO, Erminia. Habitação e Cidade. 6 ed. São Paulo: Atual, 1997. p. 8.

30 HOLANDA, Sérgio Buarque de. As Raízes do Brasil. 26 ed. São Paulo: Companhia das Letras, 1995. p. 96-98 e 107-108.

31 VIANNA JÚNIOR, Hélio. A Estrutura Interna da Cidade in: KACOWICZ, Mateus. Desenvolvimento e Política Urbana. Rio de Janeiro: IBAM, 1976. op. cit. 96-97.

${ }^{32}$ MARICATO, Erminia. Habitação... Op. cit. p. 10.

${ }^{33}$ VIANNA, Oliveira. Op. cit. p. 341.
} 
gerando uma vida urbana anormal e prematura marcada pela escassez notável de habitações para abrigo de novos moradores e moradia improvisada e insuficiente ${ }^{34}$.

Tais mazelas, não são alteradas com a mudança do ciclo econômico no século XVIII - com o declínio da produção do açúcar, a ascensão da exploração do ouro e a expansão da pecuária - e o movimento de interiorização que forjou a formação de vilas e pequenas cidades, inclusive, algumas com manifestações artísticas e culturais.

Em igual medida, as políticas normativas com a fixação de normas para ocupação do solo nos territórios de domínio português e a política de urbanização de Pombal que apesar de resultar nas grandes cidades na realização de obras públicas não foi capaz de superar a desordem na moradia urbana e a escassez habitacional nas cidades. ${ }^{35}$

Porém, incontestável que com o novo ciclo econômico reduz-se a taxa de desocupação urbana, pois com a produção de café o fazendeiro assume papel de empresário comercial e a residência urbana tem caráter de permanência bem maior, fixando uma população urbana mais numerosa e com maior poder aquisitivo. ${ }^{36}$

Neste giro, a transferência da Corte Portuguesa para o Brasil e a elevação do Brasil à categoria de Reino Unido produziu impacto no processo de urbanização, em especial, da cidade do Rio de Janeiro importando no primeiro grande conjunto de políticas públicas urbanas que gerou melhora significativa na Cidade.

Isto porque com a desocupação das principais edificações para acomodação da família real e do corpo burocrático houve a ampliação da vida cultural para população carioca e o ambiente cultural como com a construção do Teatro Municipal, da Biblioteca nacional e a Academia de Belas Artes. $^{37}$

Todavia, se por um lado reduziu a desocupação da Cidade e resultou em construções e serviços para as áreas centrais, a falta de políticas públicas urbanas capaz de garantir a moradia adequada ou o fornecimento de serviços públicos adequados agravou problemas urbanísticos decorrentes das transformações políticas e econômicas.

Por efeito, com o processo de industrialização e com a inevitável migração do campo para a cidade houve junto ao crescimento econômico a ampliação das mazelas sociais da desigualdade

\footnotetext{
${ }^{34}$ HOLANDA, Sérgio Buarque de. Op. cit. p. 92.

${ }^{35}$ MARICATO, Erminia. Habitação... Op. cit. p. 12-15.

${ }^{36}$ VIANNA JUNIOR, Helio. A Estrutura Interna da Cidade. p. 99-100.

${ }^{37}$ MARICATO, Erminia. Habitação... Op. cit. p. 16.
} 
social e a pobreza - também em nível espacial ${ }^{38}$ algo que não foi contido sequer com a tentativa de mudança da Capital para o interior ${ }^{39}$.

A falta de políticas urbanas adequadas ao surgimento da classe de trabalhadores industriais e a chegada dos escravos libertos aos núcleos urbanos agrava o crescimento desordenado das cidades acarretando demanda por moradia, transporte e serviços urbanos, além das mazelas como desemprego, criminalidade, insalubridade, epidemias e submoradias. ${ }^{40}$

Neste sentido, os poderes públicos concentram-se em políticas urbanas com fins de resolução da problemática através da tentativa de conter a ocupação irregular através da demarcação das terras devolutas e da criminalização do acesso à terra pela ocupação pura e simples pela edição da Lei de Terras ${ }^{41}$.

Ademais, ao revés de constituir políticas públicas para conter o problema fundiária editou lei civil do acesso à propriedade imóvel privada ${ }^{42}$, com a permanência de um modelo de aquisição da propriedade excludente, ocupação irregular da terra urbana e os consequentes efeitos funestos à Cidade.

Prolifera-se legislações para a edificação e código de posturas municipais que buscavam conter a proliferação de cortiços e a prática de autoconstrução da moradia, em especial, das favelas inicialmente instaladas nos morros mais próximos aos centros das respectivas cidades.

Foram adotadas políticas públicas de remoção com o despejo de famílias pobres dos conhecidos edifícios multihabitacionais conhecidos como cortiços ou "cabeças-de-porco" nas áreas centrais da cidade carioca permitindo o livre e amplo desenvolvimento da atividade econômica e ocupação das áreas por outras classes. ${ }^{43}$

Ademais, os programas urbanísticos brasileiros persistiram ligados aos ciclos econômicos, de modo que as reformas urbanas eram as medidas capazes de garantir a expansão da economia e a atração de capitais internos, que demandava nas cidades políticas públicas de ampliação do sistema viário destinado à circulação dos produtos ${ }^{44}$.

Note que houve controle social das políticas públicas urbanas do período com manifestações como a Revolta da Vacina em razão da a reforma urbana "regeneração" do Rio de

\footnotetext{
38 MARICATO, Ermínia. Metrópole na Periferia do Capitalismo. Op. Cit. p. 55.

39 SILVA, José Afonso da. Op. Cit. p. 22.

40 MARICATO, Erminia. Habitação... Op. cit. p. 27.

${ }^{41}$ BRASIL, Lei no 601 de 18 de Setembro de 1850.

${ }^{42}$ BRASIL, Lei no 3.071 de 1 de Janeiro de 1916. Art. 530.

${ }^{43}$ MARICATO, Erminia. Habitação... Op. cit. p. 28 e 30.

${ }^{44}$ MARICATO, Erminia. Habitação... Op. cit. p. 28.
} 
Janeiro sob a influência da reforma de Paris do Barão de Haussmann no governo Napoleônico de 1850 e 1870.

Em distintas cidades onde foram realizadas políticas urbanísticas de saneamento - de afastamento de setores marginalizados como miseráveis, mendigos e negros das áreas centrais embelezamento - tratamento estético e paisagístico que pressupunha a inexistência da pobreza e - segregação territorial - houveram manifestações populares. ${ }^{45}$

Neste quadro, a ausência de políticas urbanas efetivas para toda a cidade até o início do século XX gerou segregação e diferenciação na ocupação do solo urbano e na distribuição dos equipamentos públicos entre a cidade hegemônica ou oficial - garantindo benefício para os proprietários da terra e nascente capital imobiliário - e a cidade oculta ou inoficial ${ }^{46}$.

As políticas públicas da Cidade na República tem natureza excludente expulsando os setores trabalhadores e marginalizados para áreas carentes de serviços de infra-estrutura periferias, subúrbios, morros ou várzias - excetuado a extensão do transporte coletivo e serviços essenciais que viabiliza o assentamento residencial da população naquela região. ${ }^{47}$

Apenas nas primeiras quadras do século iniciam-se políticas urbanas que visaram resolver o problema de ocupação irregular nas cidades, com a criação de incentivo público para que a iniciativa privada produzisse habitação popular ${ }^{48}$, porém, o baixo poder aquisitivo da população e a concorrência da informalidade não viabilizaram a solução do problema.

O investimento pelas grandes sociedades em parcelamento de solo e comercialização de lotes enquanto o pequeno empresariado investiu na produção de pequenos núcleos - como vilas e condomínios de casa - destinada à locação, gerou altas taxas de crescimento domiciliar.

Entretanto, o aumento dos aluguéis e os baixos salários dos trabalhadores conduziu a movimentos sociais dos locatários e greve dos inquilinos gerando política urbana apenas normativa do Estado que passou a regular a locação dos prédios $^{49}$ e do uso do solo e construção das edificações resultando na edificação de escritórios e conjugados como forma de moradia. ${ }^{50}$

Com a década de 1930 que se iniciou o processo efetivo de urbanização com a previsão de uma política urbana de habitação que resultou no financiamento pelo Estado da construção de

\footnotetext{
45 MARICATO, Erminia. Habitação... Op. cit. p. 29.

${ }^{46}$ MARICATO, Erminia. Habitação... Op. cit. p. 30.

${ }^{47}$ MARICATO, Erminia. Habitação... Op. cit. p. 28.

48 MARICATO, Ermínia. Habitação... Op. cit. p. 33.

49 BRASIL, Decreto no 4.403, de 22 de Dezembro de 1921.

50 MARICATO, Ermínia. Habitação... Op. cit. p. 35.
} 
moradias, mas que acabou por importar na criação dos parques proletários destinados à transferência de favelados.

Outras intervenções estatais como o congelamento dos aluguéis ${ }^{51}$ gerou em longo prazo o desestímulo às ofertas de moradia e a Fundação da Casa Popular ${ }^{52}$ foi capaz de financiar apenas poucas moradias ${ }^{53}$ denotando a dificuldade do Estado de produzir efetivas políticas públicas urbanas para solver o problema de moradia na cidade.

Agrava-se a questão a partir da década de 50 no século XX incorporou-se de vez ao crescimento urbano do ideário urbanístico modernista em uma utopia construída por arquitetos de organização da cidade conforme suas funções através das leis de zoneamento amplamente descolada da realidade ${ }^{54}$.

Iniciam-se políticas urbanas isoladas com tratamento de qualquer problemática urbana pautou-se pela abordagem não sistematizada e casuística de aspectos locais na organização espacial intra-urbana e a remoção de estrangulamentos na infra-estrutura social básica mediante soluções setoriais isoladas, inclusive, como na habitação. ${ }^{55}$

As tentativas de coordenação de uma política urbanística em nível nacional não foram capazes de estabelecer linhas de uma ação urbana integrada. Os instrumentos de programação global de investimentos não conseguiu especificar uma função de desenvolvimento urbano. ${ }^{56}$

Houve políticas habitacionais que instituiram ao lado do regime de loteamento destinado à venda mediante pagamento do preço em prestações, um regime de urbanificação que previa a construção e casas populares com fins de garantir a eliminação de favelas, mocambos e outras aglomerações em condições subhumanas de habitação. ${ }^{57}$

Porém, as políticas públicas do Sistema Financeiro da Habitação e o Banco Nacional da Habitação acabou por agravar o problema de moradia, pois o mercado de produção de habitação se ampliou para atender a classe média e o crescimento do sistema viário aberto ocorreu para a circulação de imóveis aprofundando a segregação espacial e a exclusão social. ${ }^{58}$

\footnotetext{
${ }^{51}$ BRASIL, Decreto-Lei no 4.598, de 20 de Agosto de 1942.

52 BRASIL, Decreto-Lei no 9.777, de 6 de Setembro de 1946.

53 MARICATO, Ermínia. Habitação... Op. cit. p. 37.

54 MARICATO, Ermínia. Habitação... Op. cit. p. 37 e 39.

55 BARAT, Josef. Problemas Institucionais do Planejamento Urbano. in: KACOWICZ, Mateus. Desenvolvimento e Política Urbana. Rio de Janeiro: IBAM, 1976. p. 128/136

56 Idem. Ibidem.

57 BRASIL, Lei no 4.380 de 19 de Agosto de 1964. Art. 4ㅇ․

${ }^{58}$ MARICATO, Ermínia. Habitação... Op. cit. p. 48.
} 
Igualmente, a política normativa de editar uma lei nacional disciplinadora do parcelamento do solo urbano ${ }^{59}$ que ignorava a realidade fática social e econômica subjacente - impondo áreas mínimas e regulares para parcelamento, planos e afins - apenas agravando o crescimento da ocupação de áreas não sujeitas a controle, como de preservação ambiental ${ }^{60}$.

Sequer a edição da Constituição Federal de 1988 com ampla previsão de políticas urbanas normativas e administrativas foi capaz de alterar o cenário ${ }^{61}$. Na década de 1990 as áreas metropolitanas refletiram desigualdade social através da segregação na Cidade com ampliação dos excludentes - população de rua e comércio informal - além da violência. ${ }^{62}$

As políticas urbanas persistiran sendo marcadas pela setorialidade dos investimentos estatais com adoção apenas de planos de ação e programas apenas para as áreas valorizadas pelo mercado imobiliário ${ }^{63}$ resultando em distribuição irregular de equipamentos e serviços urbanos.

Algumas políticas normativas foram implementadas com fins a resolução do problema de moradia como o usucapião especial imóvel urbano coletivo ${ }^{64}$, a criação de um regime de urbanificações para construção de moradia de interesse social ${ }^{65}$, a concessão de uso especial para fins de moradia ${ }^{66}$ dentre outros.

Porém, apenas em meados do século XXI, que começaram a ser adotadas políticas públicas urbanas normativas e administrativas voltadas à resolver os antigos problemas das cidades brasileiras como a questão da moradia e do acesso à propriedade privada, da mobilidade e da eficiência dos transportes públicos dentre outros.

No âmbito da moradia foi adotada uma política pública nacional para facilitar o acesso à moradia própria para as famílias de menor renda através da edição de medida provisória ${ }^{67}$ posteriormente convertida em le ${ }^{68}{ }^{6}$, que instituiu a política habitacional designada Minha Casa, Minha Vida.

\footnotetext{
59 BRASIL, Lei no 6.766 de 19 de Dezembro de 1979.

60 MARICATO, Ermínia. Metrópole na Periferia do Capitalismo. Op. Cit. p. 47.

${ }^{61}$ Sobre o tema, vide: MOURA, Emerson Affonso da Costa. A Constitucionalização do Direito da Cidade. In: Vânia Siciliano Aieta. (Org.). 80 Anos de Pós-Graduação Direito UERJ: Direito da Cidade. vol. 2. 1ed.Rio de Janeiro: Freitas e Bastos, 2015.

${ }^{62}$ MARICATO, Ermínia. Metrópole... Op. Cit. p. 53-54.

63 MARICATO, Ermínia. Metrópole... Op. Cit. p. 53-54.

64 BRASIL, Projeto de Lei n. 5.788 de 1990.

65 BRASIL, Lei no 6.766 de 19 de Dezembro de 1979. Artigo 2양o com redação dada pela Lei 9.785/1999.

${ }^{66}$ BRASIL, Medida Provisória no 2.220 de 04 de Setembro de 2001.

67 BRASIL, Medida Provisória no 459 de 25 de Março de 2009.

68 BRASIL, Lei no 11.977 de 7 de Julho de 2009.
} 
Buscou-se criar mecanismos de incentivo à produção e aquisição de novas unidades habitacionais ou requalificação de imóveis urbanos e produção ou reforma de habitações rurais, para famílias com determinada renda mensal, inclusive, com a previsão de doação de terrenos públicos, desoneração tributária e instrumentos para áreas urbanas em ociosidade ${ }^{69}$.

No que se refere a mobilidade, foi editada uma Política Nacional de Mobilidade Urbana que visa garantir o melhor acesso e deslocamento de pessoas e bens no espaço urbano municipal através da integração entre os diferentes modos de transporte garantindo a prestação do serviço com equidade, eficiência e modicidade dentre outros ${ }^{70}$.

Pretende-se garantir a articulação interinstitucional entre os municípios por meio de consórcios públicos, a integração física, tarifária e operacional das redes públicas e privadas de transporte, a ocupação equilibrada da cidade de acordo com o plano diretor municipal e regional como formas de resolver o problema do custo e ineficiência do transporte brasileiro.

Note, portanto, que a cidade reflete espacialmente o tipo de relações políticas, econômicas e sociais existentes na sociedade de forma que o padrão de distribuição espacial da população nas áreas urbanas brasileiras acaba sendo orientada pelo sistema de estratificação social e determinando a ocupação e as políticas incorporando tais linhas de desigualdades. ${ }^{71}$

As políticas públicas urbanas brasileiras estiveram ligadas aos ciclos econômicos e as demandas do mercado, de forma que o acesso aos equipamentos e bens públicos ocorreu de forma excludente gerando grandes desafios no que se refere a moradia, mobilidade, serviços públicos e demais mazelas dos grandes centros urbanos.

Isto gera inevitavelmente a necessidade de garantir maior participação do grupo social na gestão democrática da cidade, em especial, no que tange ao controle nas políticas públicas urbanas de forma a permitir que tanto no planejamento quanto na execução das ações urbanísticas sejam atendidas as demandas dos usuários da cidade.

O tema será tratado a seguir.

\section{O CONTROLE SOCIAL E A GESTÃO DEMOCRÁTICA DA CIDADE}

Compreende o controle social, um conjunto de instrumentos empregados pela sociedade, capaz de induzir a conformação das pessoas às normas de comportamento que a caracteriza,

\footnotetext{
69 BRASIL, Lei no 11.977 de 7 de Julho de 2009. Art. 3ㅇ․

70 BRASIL, Lei no 12.587 de 3 de Janeiro de 2012. Art. 7.

${ }^{71}$ BRASILEIRO, Ana Maria. A Cidade: Aspectos Políticos in: KACOWICZ, Mateus .Op. cit. p. 26/27.
} 
ordenando a sua atuação no ambiente social e estabelecendo as condições necessárias para que sejam alcançados os fins e objetivos almejados pelo grupo social ${ }^{72}$.

Exterioriza-se em duas esferas de normatização distinta, conforme opere em um ambiente externo, mediante a utilização de mecanismos de constrição pela sociedade por instituições formais ou não - penas e obrigações judiciais, reprovação, admoestação social e outros - ou interno conforme sujeita a mecanismos de coerção psíquica realizada pela pessoa ${ }^{73}$.

Os instrumentos e extensão do controle social variam conforme as demandas advindas das questões políticas, econômicas, morais e afins extraídas da realidade subjacente, que importam em maior ou menor grau de inserção na esfera de autonomia das pessoas, gerando conseqüentes restrições na sua atuação externa independente sejam entes naturais ou fictícios.

Sob tal égide, sendo o Estado à expressão formal da organização político-jurídico do grupo social em dado território com objetivo de garantir sua soberania e os fins e objetivos propostos, ao qual é atribuído o exercício do poder político para a persecução destes interesses prospectivos, sua atuação igualmente se sujeita a um controle exercido pela sociedade ${ }^{74}$.

Mediante o controle social do poder se garante a cooperação entre os atores estatais e não-estatais na coordenação dos múltiplos e complexos interesses, auxiliando na formação de um espaço público que baseado na negociação e consenso atribui um maior grau de legitimidade, transparência, racionalidade e eficiência à persecução dos fins sociais ${ }^{75}$.

\footnotetext{
72 Trata-se o controle social, portanto, da capacidade de auto-regulação de um grupo social baseada na reiteração dos comportamentos necessários ou úteis para alcançar seus objetivos globais, obtidos mediante o consenso ou coerção dos indivíduos. BOBBIO, Noberto, MATTEUCCI, Nicola e PASQUINO, Gianfranco. Dicionário de Política. Brasília: Editora UNB, 1986. p. 283-284.

${ }^{73}$ Embora possa repousar a constrição no predomínio da força - mediante a utilização de instrumentos de coerção, como as penas institucionalizadas pela ordem jurídica - repousa a legitimidade do controle social, enquanto compromisso valorativo voltado à redução da coerção e alcance das metas sociais, no consenso através do reconhecimento da necessidade da prática da conduta para a realização dos fins sociais, pela utilização de debates, compromissos e outros meios. BERGALLI, Roberto. Controle Social: Suas Origens Conceituais e Usos Instrumentais in: Revista Brasileira de Ciências Instrumentais. n 3. Jul/set 1993. p. 33-34.

${ }^{74}$ Revestindo-se o poder político de atributo que o Estado concentra e exerce sob a sociedade organizada apenas como um instrumento a serviço dos seus fins supera-se a concepção da posição de supremacia dos poderes públicos nas relações com os indivíduos, para compreender que sendo a sociedade titular do poder político é a atividade estatal que se encontra subordinada aos seus interesses do grupo social e, portanto, sujeita ao seu controle.

75 Demonstra-se através da participação dos destinatários da atuação estatal no processo de deliberação pública e de fiscalização (legitimidade); nos argumentos e informações obtidos com a dialética promovida pelos atores envolvidos (racionalidade), do conhecimento das razões utilizadas como fundamentos da decisão estatal (transparência), e da escolha por consenso das medidas mais eficazes para alcançar os resultados almejados (eficiência).
} 
Importa na construção entre a sociedade e os poderes públicos de um vínculo de compromisso e responsabilidade acerca das decisões estatais, que contribui no aprimoramento dos mecanismos de exercício da cidadania, além de coibir os desvios de legalidade, garantindo previsibilidade e segurança nas relações jurídico-públicas.

Ademais, em razão da evidente ineficiência e déficit de legitimidade das políticas públicas urbanísticas na adjudicação das prestações referentes aos bens e interesses necessários a Cidade, o controle social torna-se o campo adequado para permitir a correção da atuação estatal contribuindo na busca pela efetividade das políticas públicas.

De certo, não se ignora as dificuldades na efetivação da participação dos cidadãos na gestão pública. Observa-se atualmente, dificuldades no controle social em razão do persistente desinteresse e apatia da sociedade pelo debate político ${ }^{76}$, bem como, da atuação burocrática, autoritária e hierarquizada dos poderes estatais na gestão dos interesses públicos ${ }^{77}$.

Neste tocante, erige-se a necessidade de uma otimização da publicidade dos atos estatais, de modo a viabilizar com a transparência na gestão pública o debate político ${ }^{78}$, a utilização de mecanismos de fortalecimento sócio-cultural da cidadania e fomento da participação popular ${ }^{79}$, bem como, o aperfeiçoamento da gestão estatal ${ }^{80}$ e dos instrumentos jurídicos de controle social ${ }^{81}$.

\footnotetext{
${ }^{76}$ Trata-se de fenômeno com fundamentos diversos, que variam desde a impossibilidade de participação devido às condições de pobreza extrema e baixo nível de educação de grande parte da população, da dificuldade de acesso às informações sobre as questões políticas e a falta de tempo para debater e manifestar sobre tais assuntos, até mesmo a descrença de que sua participação seja capaz de influenciar na ação pública. BARCELLOS, Ana Paula de. Papéis do Direito Constitucional no Fomento do Controle Social Democrático: Algumas Propostas Sobre o Tema da Informação in RDE ano 3. N. 12. Out/dez 2008. p. 82-84.

77 O comportamento autoritário e endógeno dos poderes instituídos, que consideram existir uma autosuficiência gerencial e política em relação à sociedade, dificulta o exercício do controle social, criando uma relação artificial e de distanciamento entre os poderes constituídos e a comunidade que deveriam servir. LEAL, Rogério. O Controle social dos serviços públicos no Brasil como condição de sua possibilidade. Revista de Direito Administrativo e Constitucional, Belo Horizonte, n. 13, jul/set 2003. p. 158.

78 Apenas com o conhecimento das informações referentes à elaboração e execução dos planos governamentais, bem como, da estrutura e modo de atuação dos órgãos político-administrativos envolvidos é capaz de ser realizado o controle social permitindo que os cidadãos possam influir na ação estatal. MILESKI, Helio Saul. Controle Social: Um Aliado do Controle Oficial. Interesse Público n. 36 mai/abr 2006. p. 87.

${ }^{79}$ Trata-se de medidas que busquem um exercício pleno da cidadania ativa necessária para o controle social, através de investimentos na educação que permitam a conscientização política e social dos cidadãos, na ampliação dos espaços públicos de atuação participativa e o desenvolvimento de uma cultura política baseada na ética. SILVA, Francisco Carlos da Cruz. Controle Social: Reformando a Administração Para a Sociedade in: Perspectivas para o Controle Social e a Transparência da Administração Pública. Brasília: Tribunal de Contas da União, Instituto Serzedello Corrêa, 2002. p. 51-55

80 Pressupõe o controle social a superação do perfil burocrático Estatal, que permita mediante a descentralização e profissionalização da gestão administrativo-financeira, um efetivo espaço de participação da sociedade na gestão dos interesses públicos e controle da atuação estatal. COELHO NETO, Milton. Ob cit. p. 316-321.
} 
Isto não importa, todavia, em desconsiderar a centralidade assumida pelo controle social na fiscalização dos poderes públicos, em especial, no que se concerne às limitações das arenas políticas e jurídicas em se tratando de controle da legitimidade e eficiência dos programas governamentais e de atribuição de responsabilidade política aos agentes estatais.

Exterioriza apenas a necessidade de aprimoramento do controle social, mediante a garantia das condições necessárias e promoção de meios capazes de ampliar a participação dos atores sociais na deliberação política estatal e a negociação com os poderes públicos nas decisões públicas, na construção de uma gestão pública comunicativa ${ }^{82}$.

O controle social pode ser exercido de forma direta pelo grupo social, através de instrumentos formais - de natureza política, administrativa ou financeira concedidos pela ordem jurídica e exercidos exclusivamente na esfera pública estatal - ou informais - não institucionalizados e promovidos no campo privado ou público não-estatal ${ }^{83}$.

Sob a égide informal compreende a mobilização organizada dos indivíduos em grupos de caráter permanente - associações, entidades e afins - ou temporário - passeatas, protestos ou outros - que buscam mediante a expressão de opinião ou reivindicação influenciar na atuação dos poderes públicos ou fomentar o debate político na sociedade ${ }^{84}$.

Ocorre através dos processos de deliberação e negociação que resultam na consolidação dos interesses do grupo social, das atividades de informação que buscam a formação e mobilização

\footnotetext{
${ }^{81}$ Torna-se necessária a construção de instrumentos jurídicos de controle social que permitam a vinculação da atuação estatal às decisões promovidas no âmbito da deliberação pública - definidas no processo eletivo e na participação na gestão estatal - e a atribuição de responsabilidade pelos desvios de eficiência e legitimidade promovidos pelos agentes públicos na persecução dos interesses públicos.

82 Neste sentido, as políticas públicas coordenadas por agentes com a participação democrática e em respeito às redes sociais, garantem os arranjos institucionais adequados e a deliberação popular nas decisões, viabilizam o desenvolvimento da sociedade. Sobre o tema, vide: SCHMIDT, João Pedro. Capital social e políticas públicas in: LEAL, Rogerio Gesta e ARAUJO, Luiz Ernane Boresso de. Direitos sociais e políticas públicas: Desafios contemporâneos. Tomo II. Santa Cruz do Sul: Edunisc, 2003. Em especial p. 446456.

${ }^{83}$ Adota-se como objeto de estudo, o controle social puro ou natural, ou seja, aquele exercido diretamente pela sociedade sobre o Estado através dos instrumentos mencionados. Não se ignora, todavia, a existência de um controle não-puro ou institucional exercido indiretamente pela sociedade através de entidades e órgãos públicos, como e.g. Ministério Público, Procons e outros, mediante instrumentos administrativos e judiciais sobre a ação estatal. Sobre a distinção: BARCELLOS, Ana Paula de. Papéis do Direito Constitucional... Ob. cit. p. 82-83.

${ }^{84}$ A mobilização dos grupos e forças que formam a sociedade civil e exercem desde a pequena ação comunitária local - impedindo a poda excessiva de árvores - até a influência sobre a opinião e atividade pública - evitando a instalação de empresa industrial cuja atividade comprometeria a qualidade de vida de uma cidade - demonstra seu importante papel na fiscalização da ação estatal e na efetividade das normas constitucionais. BARROSO, Luís Roberto. O Direito Constitucional e a efetividade de suas normas: limites e possibilidades da constituição brasileira. 2.ed. Rio de Janeiro: Renovar, 1993. p. 129-134.
} 
da opinião pública, bem como, do emprego de mecanismos de pressão ou persuasão política que tendem a interferir na tomada de decisão pública ${ }^{85}$.

Assume especial relevo no controle das políticas públicas, ao contribuir com a transparência pela divulgação das informações relativas ao planejamento, execução e resultados obtidos pela ação estatal, bem como, a legitimidade e eficiência pela expressão de aprovação ou reprovação que influi na avaliação pelos poderes públicos sobre a manutenção dos programas ${ }^{86}$.

Sob o prisma formal, o controle social abrange os instrumentos políticos decorrentes do status de cidadania, que permitem a participação direta da sociedade no exercício do poder político e na formação dos atos de governo ou a intervenção indireta na atuação política do Estado mediante a representação e fiscalização político-partidária ${ }^{87}$.

Corresponde, portanto, à ingerência dos cidadãos no processo político e na organização governamental, através do direito do sufrágio - expresso na alistabilidade e elegibilidade a cargos políticos - e de agremiação em grupos voltados à atividade política - exteriorizado na constituição, organização e participação dos partidos políticos ${ }^{88}$.

Consubstancia, também, a participação da sociedade na organização e atividade do poder estatal exercida mediante a iniciativa popular no âmbito do processo legislativo, a consulta popular na orientação ou ratificação dos atos normativos, políticos ou administrativos de governo e a tutela pela ação popular dos interesses da coletividade ${ }^{89}$.

${ }^{85}$ Embora não seja um controle institucionalizado a ordem jurídica garante o seu exercício mediante a consagração dos direitos fundamentais de liberdade de pensamento nos aspectos de crença e expressão (artigo 5o incisos IV e VI), de acesso à informação (artigo 5o inciso XIV), bem como, nos direito de reunião (artigo 5o incisos XVI) e associação (artigo 5o inciso XVII todos da Constituição) dentre outros.

${ }^{86}$ Denota-se, portanto, a importância do controle realizado pelas organizações representativas (organizações não-governamentais, associações de moradores, ouvidorias independentes...) que propiciam a captação imediata dos interesses sociais pelos poderes políticos na formulação das políticas públicas e o controle de sua atuação na execução (artigo 29 inciso X, XII, artigo 204 inciso II e artigo 227 §1ㅇtodos da Constituição).

${ }^{87}$ Neste vértice, o controle social coincide com os direitos políticos, ou seja, o complexo de direitos públicos subjetivos que investe seus titulares no status actives civitatis e permite sua participação ativa no processo político e na organização político-administrativa do Estado. CUNHA, André Luiz Nogueira da. Direitos Políticos. 1 ed. São Paulo: Juarez de Oliveira, 2004. p. 21.

${ }^{88}$ Abrange a capacidade eleitoral expressa no direito de votar (artigo $14 \$ 1$ e e 2 ㅇ da Constituição) e de ser votado (artigo 14 §3o e seguintes da Constituição), bem como, no direito de criação, fusão, incorporação e extinção dos partidos políticos (artigo 17 da Constituição e artigo 8 a 11 e 27 a 29 da Lei 9.096/95) e de filiação partidária (artigo 16 da Lei 9.096/95).

${ }^{89}$ Compreende o plebiscito (artigo 14 inciso I), o referendo (artigo 14 inciso II), a iniciativa popular (artigo 14 inciso III, artigo $27 \S 4$ e e $61 \S 2^{\circ}$ ), e ainda, a ação popular (artigo 5o

inciso LXXIII todos da Constituição) instrumento que pode ser exercido por qualquer cidadão para a anulação de qualquer ato estatal lesivo aos interesses da sociedade. 
Reveste-se de importância no controle dos programas governamentais, ao garantir a correção do planejamento e execução através da exteriorização da diretiva política almejada pela sociedade na iniciativa e consulta popular, bem como, a avaliação da ação estatal mediante a responsabilização política dos agentes no processo eletivo pelas políticas implementadas ${ }^{90}$.

O controle social compreende, ainda, instrumentos administrativos que permitem a intervenção da sociedade na persecução dos interesses públicos e o controle da atuação estatal, em um espectro que envolve desde a participação na gestão pública até a colaboração e a avaliação na promoção dos bens e serviços públicos pela Administração Pública ${ }^{91}$.

Em um contexto marcado pela crescente multiplicidade e complexidade dos interesses públicos, envolve a aferição pela Administração Pública das legítimas expectativas dos grupos sociais acerca da atuação estatal, através da coleta de opinião, do debate público ou das audiências públicas lastreando de legitimidade e impessoalidade a ação administrativa ${ }^{92}$.

Alcança as deliberações coletivas promovidas no âmbito dos órgãos estatais permanentes ou transitórios, com fins de consulta ou de decisão, como os colegiados públicos, os conselhos,

\footnotetext{
90 Observa-se, portanto, que através desses instrumentos políticos erige-se a cidadania ativa elemento condicionante da ação estatal: por meio da iniciativa popular de leis e plebiscito orientam-se os poderes públicos acerca das políticas públicas que almejadas pela sociedade devem ser implantadas; com o referendo define-se a adesão ou exclusão dos programas governamentais executados, mediante a concessão ou não de eficácia aos atos de governo; e por fim, as eleições competitivas, impõem a responsabilidade política pelos planos estatais executados e os resultados obtidos.

${ }^{91}$ Compreende, portanto, o exercício da cidadania no processo de promoção dos direitos sociais nos níveis de distribuição dos bens materiais e imateriais indispensáveis a sociedade, de forma a atribuir racionalidade, legitimidade e eficiência à gestão dos interesses sociais. MARTINS JUNIOR, Wallace Paiva. Transparência Administrativa, Publicidade, Motivação e Participação Popular. São Paulo: Saraiva, 2004. p. 298, 304 e 331.

92 Distinguem-se as formas de consulta pública quanto à eficácia produzida na discricionariedade administrativa. Assim, a coleta de opinião busca recolher mediante a utilização de canais de informação as tendências e interesses dos grupos sociais e o debate público (artigo 31 da Lei 9.784/99) tende a aferir mediante a dialética dos grupos sociais em reunião pública as distintas posições acerca de uma proposta, como atos preparatórios, facultativos e, em regra, não-vinculativos da decisão administrativa. A audiência pública (artigo 58 §2o inciso II da Constituição e artigo 32 da Lei 9.784/99), todavia, é deliberação pública que permite a exposição dos interesses, preferências e opções dos grupos sociais e vincula a ação pública pelos seus resultados. MOREIRA NETO, Diogo de Figueiredo. Direito da Participação Política. Rio de Janeiro: Renovar, 1992. p. 125-129.
} 
comitês e comissões ${ }^{93}$, que formados na sua composição por representantes da sociedade, permitem a participação da coletividade na formação da decisão pública ${ }^{94}$.

Do mesmo modo, abrange a atuação coordenada da sociedade e do ente estatal na gestão colaborada dos bens e serviços públicos, mediante o fomento das atividades privadas na função estatal pela celebração de convênios, termos de parceria, ajustes ${ }^{95}$ e outros, e na direção dos entes da Administração Pública, através da cogestão de paraestatal e demais ${ }^{96}$.

Perfaz-se, também, pela utilização de instrumentos administrativos que permitem a provocação dos órgãos de controle interno e externo, como os processos e recursos administrativos interpostos perante órgãos de revisão ou fiscalização da Administração Pública, as denúncias promovidas no âmbito do Ministério Público e outros órgãos ${ }^{97}$.

No que se refere aos programas governamentais, mediante a aferição das expectativas sociais no planejamento da ação estatal e a participação dos cidadãos nos processos decisórios na execução destes planos, se garante a correção da legitimidade da ação estatal, assim como, um maior grau de neutralidade e racionalidade nas decisões públicas ${ }^{98}$.

${ }^{93}$ Como e.g. os colegiados públicos na gestão administrativa da seguridade social (artigo 194 inciso VII), da saúde (artigo 198 inciso III), da assistência social (artigo 204 inciso II), do ensino público (artigo 206 inciso VI), da fixação de política agrícola (artigo 187), ou os conselhos estatais, tal qual o Conselho da República (artigo 89 inciso VII), Conselho Nacional de Justiça (artigo 103-B inciso XIII), Conselho Nacional do Ministério Público (artigo 130-A inciso VI todos da Constituição) dentre outros.

${ }^{94}$ Não obstante, a participação popular nos órgãos de consulta e decisão represente importante instrumento de controle social, observa-se na prática uma falta de real representatividade dos membros escolhidos, uma vez que não são eleitos pela sociedade e geralmente integram o próprio poder público. DI PIETRO, Maria Sylvia Zanella. Participação Popular na Administração Pública. Revista de Direito Administrativo n. 191 jan/mar 2003. p. 35.

95 Os contratos de gestão e os termos de parceria firmados entre o poder público e as organizações sociais ou sociedades civis de interesse público respectivamente exercem importante papel nas políticas de promoção dos direitos sociais (educação, saúde, cultura...), estão sujeitos, também, a controle realizado pelos demais segmentos da sociedade. (Artigo 20 inciso III da Lei 9.637/98 e artigo 11 Caput e §3으 da Lei 9.790/99)

96 Ocorre mediante a composição por representantes populares nos órgãos de gestão e direção das paraestatais - como diretorias ou conselhos responsáveis - cuja técnica de escolha e investidura variará conforme a natureza destas entidades de índole executiva de atividades sociais ou econômicas do Estado. MOREIRA NETO, Diogo de Figueiredo. Direito da Participação... Ob. cit. p. 133.

${ }^{97} \mathrm{O}$ controle social abrange, ainda, outros instrumentos administrativos como o direito de petição (artigo 5 은 inciso XXXIV alínea "a" da Constituição), de informação (artigo 5o inciso XIV e XXXIII da Constituição e Artigo 14 §6o da Lei 11.079/04), de fiscalização e reclamação dos serviços públicos (Artigo 58 §2o inciso IV da Constituição, Artigo 3o, 29 inciso XII e 30 §único da Lei 8.987/95 e Artigo 33 da Lei 9.074/95), a assessoria externa, delegação atípica dentre outros. Sobre o tema, vide: SCHIER, Adriana da Costa R. A Participação popular na administração pública: o direito de reclamação. São Paulo: Renovar, 2002.

98 A participação de sujeitos que possam trazer diferentes perspectivas de resolução, por vezes, com conhecimentos específicos sobre o tema, melhora a qualidade das decisões administrativas pela melhor compreensão da dimensão e possíveis soluções do problema, além de permitir com a abertura do processo 
Com o consenso administrativo no planejamento e execução das políticas públicas se permite, através da harmonia e conjugação das atividades estatais e privadas, a obtenção dos elementos necessários para a garantia do atendimento das demandas sociais com a ampliação do grau de eficiência no oferecimento dos respectivos bens e serviços públicos ${ }^{99}$.

A partir dos instrumentos de informação administrativa e provocação dos órgãos de controle interno e externo da atuação estatal, orienta-se a avaliação das políticas públicas, garantindo a transparência e correção de legalidade dos programas de governo, bem como, a responsabilização dos agentes estatais contribuindo para o aprimoramento da ação pública ${ }^{100}$.

Por fim, o controle social envolve instrumentos financeiros que incidem sobre a alocação prévia e abstrata dos recursos públicos nas leis orçamentárias e seu dispêndio na execução promovida pelas unidades orçamentárias, de forma a assegurar a transparência financeiroorçamentária, a gestão responsável dos recursos e a responsabilidade fiscal.

Compreende a exigência de clareza e simplicidade das leis instituidoras de tributos, de feitura do orçamento e controle de sua execução, bem como, o dever de otimização de publicidade das informações fiscais, que permitem o desenho da estrutura e política financeira adotada pelo governo viabilizando o monitoramento dos gastos públicos ${ }^{101}$.

Abrange a participação da sociedade no âmbito do processo financeiro, exteriorizada na consulta popular ou deliberação pública promovida durante o planejamento orçamentário, e na

decisório aos vários atores sociais, maior facilidade de aceitação pelos seus destinatários. SILVA, Vasco Manuel Pascoal Pereira da. Em busca do Acto Administrativo Permitido. Coimbra: Almedina, 1998. p. 402.

${ }^{99} \mathrm{~A}$ utilização de formas consensuais na ação administrativa, em especial, nas atividades de planejamento e execução, garante maior grau de agilidade, elasticidade e adaptabilidade na dialética dos interesses que orientam a ação administrativa, ampliando a transparência e eficiência na superação negociada dos conflitos destes interesses. BAPTISTA, Patrícia. Transformações do Direito Administrativo. Rio de Janeiro: Renovar, 2003. p. 270 e 267.

100 Denota-se, portanto, a importância dos instrumentos de publicidade, que permitem a transparência de todo o ciclo da política pública e avaliação da relação de conformidade entre as propostas e os programas implementados, as expectativas sociais e os resultados efetivamente alcançados e as conseqüentes correções da ação estatal. VALLE, Vanice Lirio do. Ob cit. p. 104.

${ }^{101}$ Através da ampla comunicação dos dados acerca da arrecadação e gastos públicos (artigo 165 §6o da Constituição), da ação estatal (artigo 1ㅇำ $§ 10$ da Lei de Responsabilidade Fiscal), do conteúdo da legislação tributária (artigo 150 §50 da Constituição), bem como, dos atos orçamentários, relatórios e balancetes periódicos (artigo 31 §3ㅇ da Constituição) garante-se a transparência fiscal necessária para o controle das renúncias e receitas, a declaração de direito dos contribuintes e o combate à corrupção. TORRES, Ricardo Lobo. O Princípio da Transparência e o Direito Financeiro. p. 9. Mundo Jurídico. Disponível em: http://www.mundojuridico.adv.br/sis_artigos/artigos.asp?codigo=162. Acesso em: 25 maio de 2010. 
gestão colaborada dos recursos financeiros dentre outros capazes de garantir uma atuação democrática dos poderes públicos voltada ao atendimento dos reais interesses do grupo social ${ }^{102}$.

Exerce-se, ainda, o controle financeiro-orçamentário pela comunidade mediante a fiscalização popular das contas públicas, a propositura da ação popular e as denúncias de irregularidade aos Tribunais de Contas, que permitem a correção das medidas implementadas aos resultados esperados da política fiscal e a responsabilização dos agentes públicos ${ }^{103}$.

Guarda peculiar importância no que tange as políticas públicas, uma vez que através da atividade financeira exercida pelo Estado são obtidos e geridos os recursos indispensáveis à fruição dos bens e interesses sociais e com a previsão das despesas nas leis orçamentárias são programados os dispêndios necessários para a promoção dos bens e serviços ${ }^{104}$.

Neste tocante, no âmbito do controle social das questões urbanas, com a edição do Estatuto da Cidade vários instrumentos foram instituídos para garantir a participação dos proprietários, moradores, usuários permanentes e investidores na formulação, implementação e controle das políticas públicas urbanas.

Por efeito, consagra a lei como princípio a gestão democrática da cidade, que garante por meio da participação da população e de associações representativas dos vários segmentos da comunidade na formulação, execução e acompanhamento de planos, programas e projetos de desenvolvimento urbano. ${ }^{105}$

Neste sentido, impõe dentro do planejamento das políticas urbanas municipais do instrumento de gestão orçamentária participativa ${ }^{106}$, a saber, o controle social financeiro-

102 Como e.g. a realização de audiências públicas, durante os processos de elaboração e discussão das leis orçamentárias (artigo 48 §único da Lei de Responsabilidade Fiscal e Artigo 2o inciso VII do Decreto 5.019/04), a gestão dos Fundos de Pobreza por entidades que contenham a participação da sociedade civil (artigo 82 dos Atos das Disposições Constitucionais Transitórias) e a participação popular na elaboração, definição e execução do orçamento (artigo 116 §1으 da Lei Orgânica do Município de Porto Alegre e outros) no chamado orçamento participativo.

${ }^{103}$ Abrange o ciclo orçamentário no seu vértice o controle da execução da política financeira que não compreende apenas o orçamento, mas o balanço patrimonial e outros documentos e a apreciação das contas que não envolve somente o parecer do Tribunal de Contas ou julgamento pelo Congresso Nacional, mas também a accountability promovida pela sociedade (artigo 31 §3ㅇ, artigo 74 §2o da Constituição dentre outros). BALLEIRO, Aliomar. Uma Introdução a Ciência das Finanças. 16 ed. Rio de Janeiro: Forense, 2004. p. 412 e 445.

104 Neste sentido, as leis orçamentárias não devem ser compreendidas apenas como peças de natureza contábil que contém a programação das receitas previstas e despesas autorizadas, porém, a exteriorização dos programas ou planos de atuação governamental e diretiva política da sociedade, que busca suprir as demandas sociais e regular a esfera econômico-social. SILVA, José Afonso da. Orçamento-programa no Brasil. São Paulo: Revista dos Tribunais. 1973. p. 01-03 e 40.

${ }^{105}$ BRASIL, Lei Federal no 10.257/2001. Art. 2 Inciso II.

106 BRASIL, Lei Federal no 10.257/2001. Art. 4 Inciso III "f". 
orçamentário sobre as escolhas acercas dos programas e planos de ações a serem desenvolvidos em relação à Cidade.

Isto inclui, portanto, a participação popular na elaboração do plano diretor, que ocorrerá mediante a garantia da realização de audiências públicas e debates com segmentos da população, a publicização dos documentos e informações produzidas e o acesso à qualquer interessado a qualquer um dos documentos. ${ }^{107}$

Porém, não se limita a legislação de ordenação urbanística impondo a realização de debates, audiências e consultas públicas sobre as propostas das leis orçamentárias municipais - o plano plurianual, da lei de diretrizes orçamentárias e o orçamento anual - como condição obrigatória para a sua aprovação pela Câmara Municipal. ${ }^{108}$

Envolve instrumentos capazes de garantir uma gestão democrática da cidade como a formação de órgãos colegiados de política urbana, realização de debates, audiências e consultas públicas, conferências sobre assuntos de interesse urbano, nos níveis nacional, estadual e municipal, além de iniciativa popular de projeto de lei e de planos e programas. ${ }^{109}$

Prevê, também, a garantia da participação de comunidades, movimentos e entidades da sociedade civil em qualquer outro instrumento político-jurídico de planejamento municipal, metropolitano, bem como, estadual, regional ou nacional, que seja adotado que gere dispêndio de recursos pelo Poder Público Municipal. ${ }^{110}$

Em específico, determina que as intervenções e medidas coordenadas pelo Poder Público Municipal no âmbito das Operações Urbanas Consorciadas apenas ocorrerá com a participação dos sujeitos da Cidade - proprietários, moradores, usuários e investidores - na definição da transformações, melhorias sociais e a valorização ambiental almejadas ${ }^{111}$.

O Estatuto da Cidade define o controle social no âmbito da execução das políticas urbanas municipais ao determinar a participação na implementação do plano diretor com igual direito a informação e de garantia de acesso aos documentos, bem como, a realização de audiências e consultas públicas ${ }^{112}$.

Isto abrange os instrumentos financeiros, pois demanda dos gestores das regiões metropolitanas e aglomerações urbanas a obrigatória participação da população e de associações

\footnotetext{
107 BRASIL, Lei Federal no 10.257/2001. Art. 40 §4ㅇ․

108 BRASIL, Lei Federal no 10.257/2001. Art. 44.

109 BRASIL, Lei Federal no 10.257/2001. Art. 43.

110 BRASIL, Lei Federal no 10.257/2001. Art. 4 §3ㅇ․

111 BRASIL, Lei Federal no 10.257/2001. Art. 32 §1ㅇ․

112 BRASIL, Lei Federal no 10.257/2001. Art. 40 §4ㅇ․
} 
representativas dos vários segmentos da comunidade na gestão dos recursos, de modo a garantir o controle direto de suas atividades e o pleno exercício da cidadania. ${ }^{113}$

Note, portanto, que no âmbito da legislação urbanística foram previstos instrumentos administrativos e financeiros de controle sobre o planejamento e a execução das políticas públicas urbanas, como forma de garantir a realização do princípio democrático no âmbito da gestão das cidades e conformar os programas de ação governamental aos fins desejados.

Com a gestão democrática da cidade garante-se que a realização das ações municipais de acordo com as funções sociais do núcleo urbano - moradia, lazer, mobilidade, transporte - possam ser fiscalizadas não apenas após a concretização dos planos de ação, mas desde o momento de sua programação orçamentária e planejamento administrativo.

Assim, reconduz-se a ação administrativa e legislativa à Constituição Federal de 1988, que fixa não somente competências para instituir planos urbanísticos, mas cria por si só uma Política Pública Urbana Constitucional, com fins de ordenar o pleno desenvolvimento das funções sociais da cidade, bem como, garantir o bem- estar de seus habitantes. ${ }^{114}$

Com gestão democrática as funções tipicamente sociais - de habitação, trabalho, lazer e mobilidade - de cidadania - como educação, saúde, segurança e proteção - e de gestão - como a prestação de serviços, planejamento, preservação do patrimônio cultural e natural, e sustentabilidade urbana ${ }^{115}$ passam a entrar em pauta na formulação das políticas públicas.

Por efeito, com tais instrumentos é possível garantir políticas urbanas não apenas eficientes, mas igualmente, sustentáveis, exigindo na gestão pública mudanças nos padrões de produção e consumo de recursos de acordo uma educação ambiental garantindo redução de desperdícios, fomento a tecnologias urbanas sustentáveis e afins. ${ }^{116}$

Isto porque, embora inegáveis políticas públicas urbanas tenham sido promovida nos últimos anos e tenha se ampliado a acúmulo de práticas participativas na gestão da cidade, há o

\footnotetext{
113 BRASIL, Lei Federal no 10.257/2001. Art. 45.

114 Sobre o tema, vide: MOURA, Emerson Affonso da Costa. A Constitucionalização do Direito da Cidade. In: Vânia Siciliano Aieta. (Org.). 80 Anos de Pós-Graduação Direito UERJ: Direito da Cidade. vol. 2. 1ed.Rio de Janeiro: Freitas e Bastos, 2015.

115 Sobre o tema, vide: BERNARDI, Jorge Luiz; GARCIAS, Carlos Mello. As Funções Sociais da Cidade. Revista Direitos Fundamentais e Democracia. Vol 4. 1998

116 SILVA, Solange Teles. Políticas Públicas e Estratégia de Sustentabilidade Urbana. Revista de Direito Ambiental da Amazônia, agosto-dezembro 2003, pp. 136.
} 
desafio de garantir a integração das ações governamentais e do controle social em um sistema efetivo de participação e representação democrática. ${ }^{117}$

Por um lado, tais instrumentos de controle social previstos no Estatuto da Cidade permitem uma democratização não apenas do próprio processo de tomada de decisão, mas corresponde a verdadeiro instrumento de superação da exclusão social na Cidade permitindo uma conexão entre a cidade legal e real. ${ }^{118}$

Por outro, todavia, há um grande risco de captação por práticas culturais como o clientelismo com a captação pelos atores políticos dos recursos públicos para reprodução social das mazelas da Cidade mediante o atendimento de dado grupo eleitoral, mediante a troca de bens e recursos por votos e apoio. ${ }^{119}$

Há, portanto, riscos e dificuldades inerentes ao processo de controle social no âmbito das políticas públicas urbanísticas, todavia, o potencial da participação no planejamento e na execução dos programas de ação urbana podem corrigir a longo prazo as distorções produzidas ao longo da história na má gestão e distribuição dos recursos na Cidade.

\section{CONCLUSÃO}

Traduzem-se as políticas públicas em planos de ação que buscam conformar os objetivos da ordem econômica e social permitindo o oferecimento de bens, utilidades e serviços que garantam a realização de tais fins e a concretização dos bens, interesses e direitos eleitos pela sociedade na Constituição.

Em matéria de Cidade são o instrumento de realização das funções sociais da Cidade garantindo o pleno desenvolvimento humano, social e ambiental, de modo que através dos programas e ações estatais, que se permite conformar a gestão e expansão dos núcleos urbanos aos fins socialmente almejados.

Marcada por um histórico de vinculação a finalidades econômicas ligando-se as políticas públicas da Colônia e do Império aos ciclos de exploração dos recursos naturais e na República ao

117 TONELLA, Célia. Políticas Urbanas no Brasil: marcos legais, sujeitos e instituições. Revista Sociedade e Estado - Volume 28 Número 1 - Janeiro/Abril 2013. p. 49.

118 BUCCI, Maria Paulo Dallari. Gestão democrática da cidade. In: DALLARI, Adilson Abreu; FERRAZ, Sérgio. Estatuto da Cidade: comentários à Lei Federal 10.257/2001. São Paulo: Malheiros Editores, 2002. p. 324

119 NOVAES, Patrícia Ramos; QUINTSLR, Suyá. Critérios de Avaliação de Políticas Públicas: clientelismo versus universalismo de procedimentos in: SANTOS JUNIOR, Orlando Alves; CHRISTOVÃO, Ana Carolina; NOVAES, Patricia Ramos. Políticas públicas e direito à cidade : programa interdisciplinar de formação de agentes sociais e conselheiros municipais. Rio de Janeiro: Letra Capital, 2011. p. 28. 
desenvolvimento da atividade econômica e o interesse do mercado, os programas urbanísticos brasileiros resultaram ineficazes no que tange a plena realização da Cidade.

Em um Estado Democrático de Direito com epicentro na Constituição Cidadã voltada a redução das desigualdades econômicas e sociais, as políticas públicas devem ser tidas como planos de ação vinculados não apenas aos deveres impostos pela Constituição Federal, mas a realização do princípio democrático com ampla participação da sociedade.

Neste sentido, apenas através do aperfeiçoamento do controle social mediante a ampla participação dos sujeitos da Cidade - proprietários, moradores, usuários e investidores - na tomada de decisão e no controle do planejamento e execução dos programas urbanísticos, inclusive, os orçamentos que destinam verbas à Cidade será capaz de ser alterado o status quo.

Com o Estatuto da Cidade foi previsto o princípio da gestão democrática da cidade com a consagração de inúmeros instrumentos capazes de garantir o controle das políticas públicas urbanas, o que demanda, todavia, a necessidade de aplica-lo não através de práticas clientelistas, mas como instrumento de garantia de cidadania e redução da desigualdade na Cidade.

Através do controle social das políticas urbanas é possível reduzir os níveis de exclusão social e segregação espacial na Cidade ao exigir que a distribuição dos recursos e políticas ocorram de forma a atender as funções sociais da Cidade e garantir o desenvolvimento humano, social e ambiental não só na cidade formal, mas na cidade real.

\section{REFERÊNCIAS}

BALLEIRO, Aliomar. Uma Introdução a Ciência das Finanças. 16 ed. Rio de Janeiro: Forense, 2004.

BAPTISTA, Patrícia. Transformações do Direito Administrativo. Rio de Janeiro: Renovar, 2003.

BARAT, Josef. Problemas Institucionais do Planejamento Urbano. in: KACOWICZ, Mateus.

Desenvolvimento e Política Urbana. Rio de Janeiro: IBAM, 1976.

BARCELLOS, Ana Paula de. Constitucionalização das Políticas Públicas em Matéria de Direitos Fundamentais: O Controle Político-Social e o Controle Jurídico no Espaço Democrático in Revista de Direito do Estado. Ano 1. n. 3. 2006.

Papéis do Direito Constitucional no Fomento do Controle Social Democrático: Algumas Propostas Sobre o Tema da Informação in RDE ano 3. N. 12. Out/dez 2008.

BARROS, Ricardo Paes, HENRIQUES, Ricardo e MENDONÇA, Rosane. A Estabilidade Inaceitável: desigualdade e pobreza no Brasil. Rio de Janeiro: Ipea, 2001. 
BARROSO, Luís Roberto. Neoconstitucionalismo e constitucionalização do direito: O triunfo tardio do direito constitucional no Brasil. In: SOUZA NETO, Cláudio Pereira de; SARMENTO, Daniel (orgs.). A constitucionalização do direito: fundamentos teóricos e aplicações específicas. Rio de Janeiro: Lumen Juris, 2007.

o Direito Constitucional e a efetividade de suas normas: limites e possibilidades da constituição brasileira. 2.ed. Rio de Janeiro: Renovar, 1993.

BERGALLI, Roberto. Controle Social: Suas Origens Conceituais e Usos Instrumentais in: Revista Brasileira de Ciências Instrumentais. n 3. Jul/set 1993.

BERNARDI, Jorge Luiz; GARCIAS, Carlos Mello. As Funções Sociais da Cidade. Revista Direitos Fundamentais e Democracia. Vol 4. 1998.

BRASILEIRO, Ana Maria. A Cidade: Aspectos Políticos in: KACOWICZ, Mateus. Desenvolvimento e Política Urbana. Rio de Janeiro: IBAM, 1976.

BOBBIO, Noberto, MATTEUCCI, Nicola e PASQUINO, Gianfranco. Dicionário de Política. Brasília: Editora UNB, 1986.

BOSCO, Maria Goretti. Discricionariedade em políticas públicas. Curitiba: Juruá, 2007.

BUCCI, Maria Paula Dallari. Direito Administrativo e Políticas Públicas. São Paulo: Saraiva, 2002.

CAETANO, Marcello. Manual de Ciência Política e de Direito Constitucional. Coimbra: Almedina, 2003.

COELHO NETO, Milton. A Transparência e o Controle social como Paradigmas para a Gestão Pública no Estado Moderno in: FIGUEIREDO, Carlos Maurício e NÓBREGA, Marcos. Administração Pública: Direito Administrativo, Financeiro e Gestão Pública: Prática, Inovações e Polêmicas. São Paulo: Revista dos Tribunais, 2002.

DERBLI, Felipe. Proibição de Retrocesso Social: Uma Proposta de Sistematização à Luz da Constituição de 1988 in: BARROSO, Luís Roberto (Org). A Reconstrução Democrática do Direito Público no Brasil. Renovar: Rio de Janeiro, 2007.

DI PIETRO, Maria Sylvia Zanella. Participação Popular na Administração Pública. Revista de Direito Administrativo n. 191 jan/mar 2003.

HESSE, Konrad. A força normativa da Constituição. Porto Alegre: Sergio Antonio Fabris Ed., 1991.

HOLANDA, Sérgio Buarque de. As Raízes do Brasil. 26 ed. São Paulo: Companhia das Letras, 1995.

LEAL, Rogério. O Controle social dos serviços públicos no Brasil como condição de sua possibilidade. Revista de Direito Administrativo e Constitucional, Belo Horizonte, n. 13, jul/set 2003. ARAUJO, Luiz Ernane Boresso de. Direitos sociais e políticas públicas: Desafios contemporâneos. Tomo II. Santa Cruz do Sul: Edunisc, 2003. 
LEITE, Fereira Harrison. Segurança Jurídica e Elaboração do Orçamento Público. Revista Tributária e de Finanças Públicas. n 86 mai/jul 2009.

MARICATO, Erminia. Habitação e Cidade. 6 ed. São Paulo: Atual, 1997. Metrópole na Periferia do Capitalismo. São Paulo: Hucitec, 1996.

MENY, Ives e Thoenig, Jean Claude. Lãs políticas públicas. Barcelona: Ariel, 1992.

MILESKI, Helio Saul. Controle Social: Um Aliado do Controle Oficial. Interesse Público n. 36 mai/abr 2006.

COELHO NETO, Milton. A Transparência e o Controle Social como Paradigmas para a Gestão Pública no Estado Moderno in: FIGUEIREDO, Carlos Maurício e NÓBREGA, Marcos. Administração Pública: Direito Administrativo, Financeiro e Gestão Pública: Prática, Inovações e Polêmicas. São Paulo: Revista dos Tribunais, 2002.

CUNHA, André Luiz Nogueira da. Direitos Políticos. 1 ed. São Paulo: Juarez de Oliveira, 2004.

MARTINS JUNIOR, Wallace Paiva. Transparência Administrativa, Publicidade, Motivação e Participação Popular. São Paulo: Saraiva, 2004.

MIRANDA, Jorge. Manual de Direito Constitucional Tomo IV Direitos Fundamentais. Coimbra: Coimbra Editores, 2002.

MOREIRA NETO, Diogo de Figueiredo. Quatro Paradigmas do Direito Administrativo Pós-Moderno. Belo Horizonte: Fórum, 2008.

Direito da Participação Política. Rio de Janeiro: Renovar, 1992.

MOURA, Emerson Affonso da Costa. Agências, Expertise e Profissionalismo: O Paradigma da Técnica na Administração Pública. Revista de Direito Administrativo, v. 254, p. 79, 2011.

A Constitucionalização do Direito da Cidade. In: Vânia Siciliano Aieta. (Org.). 80 Anos de PósGraduação Direito UERJ: Direito da Cidade. vol. 2. 1ed.Rio de Janeiro: Freitas e Bastos, 2015.

NOVAES, Patrícia Ramos; QUINTSLR, Suyá. Critérios de Avaliação de Políticas Públicas: clientelismo versus universalismo de procedimentos in: SANTOS JUNIOR, Orlando Alves; CHRISTOVÃO, Ana Carolina; NOVAES, Patricia Ramos. Políticas públicas e direito à cidade: programa interdisciplinar de formação de agentes sociais e conselheiros municipais. Rio de Janeiro: Letra Capital, 2011.

OLIVEIRA, Farlei Martins Riccio de. Controle de Legitimidade das Políticas Públicas: Limites e Possibilidades. Revista de Direito Administrativo, 247 jan/abr de 2008.

SARMENTO, Daniel. O neoconstitucionalismo no Brasil: Riscos e possibilidades. In: (org.). Filosofia e teoria constitucional contemporânea. Rio de Janeiro: Lumen Juris, 2009.

SCHIER, Adriana da Costa R. A Participação popular na administração pública: o direito de reclamação. São Paulo: Renovar, 2002. 
SILVA, Francisco Carlos da Cruz. Controle Social: Reformando a Administração Para a Sociedade in: Perspectivas para o Controle Social e a Transparência da Administração Pública. Brasília: Tribunal de Contas da União, Instituto Serzedello Corrêa, 2002.

SILVA, José Afonso da. Direito Urbanístico Brasileiro. 7 ed. São Paulo: Malheiros, 2012. Orçamento-programa no Brasil. São Paulo: Revista dos Tribunais. 1973.

SILVA, Pedro Luiz Barros e MELO, Marcus André Barreto de. O Processo de Implementação de Políticas Públicas no Brasil: Características e Determinantes da Avaliação de Programas e Projetos. Caderno do Núcleo de Estudos de Políticas Públicas da Unicamp n. 48. SILVA, Solange Teles. Políticas Públicas e Estratégia de Sustentabilidade Urbana. Revista de Direito Ambiental da Amazônia, agosto-dezembro 2003.

SILVA, Vasco Manuel Pascoal Pereira da. Em busca do Acto Administrativo Permitido. Coimbra: Almedina, 1998.

TONELLA, Célia. Políticas Urbanas no Brasil: marcos legais, sujeitos e instituições. Revista Sociedade e Estado - Volume 28 Número 1 - Janeiro/Abril 2013.

TORRES, Ricardo Lobo. Tratado de Direito Constitucional, Financeiro e Tributário: O Orçamento na Constituição. 3. ed. Rio de Janeiro: Renovar, 2008.

o Princípio da Transparência e o Direito Financeiro. p. 9. Mundo Jurídico. Disponível em: http://www.mundojuridico.adv.br/sis_artigos/artigos.asp?codigo=162. Acesso em: 25 maio de 2010.

VALLE, Vanice Lirio do. Direito fundamental a boa administração, Políticas Públicas Eficientes e a Prevenção do Desgoverno. Revista Interesse Público, n. 48 mar/abr de 2007.

VIANNA, Oliveira. Populações Meridionais do Brasil. Brasília: Senado Federal, 2005.

VIANNA JÚNIOR, Hélio. A Estrutura Interna da Cidade in: KACOWICZ, Mateus. Desenvolvimento e Política Urbana. Rio de Janeiro: IBAM, 1976.

Trabalho enviado em 14 de abril de 2016.

Aceito em 17 de julho de 2016. 